\title{
Keinginan Berhenti Merokok Pada Pelajar Perokok Berdasarkan Global Youth Tobacco Survey di SMK Negeri Kota Padang
}

\author{
Sulastri ${ }^{1}$, Deddy Herman ${ }^{2}$, Eryati Darwin ${ }^{3}$
}

\begin{abstract}
Abstrak
Remaja menjadi salah satu pengguna rokok dengan prevalensi yang terus meningkat hal ini dipengaruhi oleh banyak faktor yang juga berkaitan dengan kepribadian dan lingkungan remaja. Berdasarkan Factsheet Global Youth Tobacco Survey di Indonesia memaparkan 4 dari 5 orang perokok berkeinginan untuk berhenti merokok. Banyak perokok menyadari risikonya dan termotivasi untuk berhenti merokok, namun mengalami kesulitan untuk berhenti merokok. Tujuan penelitian ini adalah mengetahui keinginan berhenti merokok pada pelajar SMK Negeri di kota Padang. Jenis penelitian ini adalah deskriptif dengan desain penelitian potong lintang. Jumlah sampel pada penelitian ini adalah 166 orang siswa perokok SMK Negeri di Kota Padang pada tahun 2018 dengan menggunakan kuesioner Global Youth Tobacco Survey, berbahasa Indonesia. Hasil penelitian ini didapatkan bahwa pelajar perokok di SMKN kota Padang adalah $43,10 \%$. Sebagian besar perokok adalah laki-laki. Sebanyak $43,40 \%$ siswa mulai merokok pada usia pada kelompok usia 14-15 tahun. Sekitar $64,45 \%$ berkeingian untuk berhenti merokok. Penelitian ini dapat disimpulkan bahwa terdapat kurang dari separuh siswa di sekolah tersebut merupakan perokok. Ditemukan sebagian kecil siswa perempuan pernah mencoba rokok dan usia terbanyak mulai merokok adalah usia 14-15 tahun. Sebagian besar pelajar perokok berkeinginan untuk berhenti merokok.
\end{abstract}

Kata kunci: merokok, global youth tobacco survey, remaja, keinginan berhenti merokok

\begin{abstract}
Teenager show increasing prevalence on smoking that could be due to many factors such as personality and environment. Factsheet Global Youth Tobacco Survey in Indonesia revealed that 4 out of 5 smokers actually want to quit. Many smokers realize the risk of smoking and motivated to quit with many difficulties. The objective of this study was to know the students who smoke were aspiring to quit in public vocational school in Padang. This cross-sectional descriptive study was conducted on 166 student in public vocational school in Padang City on 2018 by using Global Youth Tobacco Survey quesionnaires in Bahasa. The study showed that students in public vocational school in Padang City who smoke were $43.10 \%$ with men dominated. As many as $43.4 \%$ students started to smoke in $14-15$ years old with $64.45 \%$ were aspiring to quit. The study concluded that there is less than half students in the school who smoke. In small amount of female students ever tried to smoke and the most of them in 14-15 years old. Most of the students who smoke were aspiring to quit.
\end{abstract}

Keywords: smoking, global youth tobacco survey, teenager, smoking cessation aspiration

Affiliasi penulis: 1. Prodi Kedokteran Fakultas Kedokteran Universitas Andalas Padang (FK Unand), 2. Bagian Paru FK Unand, 3. Bagian Histologi FK Unand

Korespondensi: Sulastri, email: ilasadek92@gmail.com Telp: 082285983181

\section{PENDAHULUAN}

Indonesia merupakan salah satu negara yang masih mengalami pertumbuhan dalam sektor industri. ${ }^{1}$ Pertanian tembakau dan industri pengolahan tembakau dinilai dapat meningkatan sektor perindustrian nasional 
di Indonesia khususnya dalam penggunaan produk tembakau, dalam hal ini adalah rokok. $^{2}$ Indonesia menempati peringkat ke-5 sebagai produsen tembakau dunia. $^{3}$ Terdapat 1.132 pabrik rokok di indonesia dan merupakan jumlah terbesar di seluruh dunia. Sekitar 800 pabrik rokok berada di tiga provinsi, yakni Jawa Tengah, Jawa Timur dan Nusa Tenggara Barat yang merupakan daerah penghasil tembakau terbesar nasional. ${ }^{3,4}$ Industri ini melibatkan jutaan orang pekerja, hingga tahun 2013 terhitung ada sekitar 114 juta orang diantaranya sekitar 40 juta (35\%) di sektor pertanian, 29 juta (25\%) di sektor industri, dan 45 juta (45\%) di sektor jasa distribusi rokok di indonesia. ${ }^{3}$ Keadaan ini menjadi alasan produksi rokok terus meningkat dan belum dapat dituntaskan. ${ }^{4}$

Menurut Riset Nasional Dasar Kesehatan 2013, prevalensi merokok di Indonesia yang berusia 15 tahun ke atas meningkat dari 34,2\% di 2007 menjadi 34,7\% pada tahun 2010, dan menjadi 36,3\% pada tahun 2013. Persentase memulai menggunakan tembakau dalam setiap kelompok usia adalah: 5-9 tahun - 0,7\%, 10-14 tahun 9,5\%, 15-19 tahun 50,3\%, 20-24 tahun 26,7\%, 25-29 tahun 7,6\%, > 30 tahun 5,2\%. ${ }^{5}$

Merokok masih menjadi salah satu masalah terbesar kesehatan yang dapat menyebabkan kematian. ${ }^{6}$ Pada tahun 2015, lebih dari 1,1 miliar orang merokok dengan bahan utama tembakau. Sekitar 6 juta orang perokok aktif di seluruh dunia mengalami kematian setiap tahun dan sekitar 600 ribu orang perokok pasif yang juga diperkirakan meninggal akibat paparan asap rokok secara langsung. Diperkirakan pada tahun 2030 lebih dari 8 juta kematian diakibatkan oleh rokok, lebih dari separuhnya merupakan usia awal memulai menggunakan rokok. $^{7}$ Berdasarkan hasil penelitian WHO di Indonesia menyatakan bahwa penggunaan tembakau dalam bentuk rokok yaitu sebanyak $34,8 \%$ atau 59,9 juta penduduk dari seluruh bentuk penggunaan tembakau di Indonesia. Prevalensi merokok di Indonesia adalah 67\% atau 57,6 juta penduduk laki-laki dan $2,7 \%$ atau 2,3 juta penduduk perempuan. $^{7}$

Penelitian telah banyak dilakukan guna menjelaskan perilaku merokok remaja di Indonesia, namun pembahasan tentang perilaku berhenti merokok di kalangan generasi muda masih relatif terbatas. ${ }^{8}$
Alasan gangguan kesehatan dan kerugian ekonomi hampir merata ditemukan pada perokok yang ingin menghentikan kebiasaan merokok. ${ }^{9}$ Selain itu, dukungan dari orang terdekat juga menjadi motivasi untuk berhenti merokok. ${ }^{10}$

Data Kemenkes menunjukkan bahwa prevalensi remaja usia 16-19 tahun yang merokok meningkat 3 kali lipat dari 7,1\% di tahun 1995 menjadi 20,3\% pada tahun 2009 dan menurun menjadi 18,3\% pada tahun 2014 setelah dilakukan penelitian dengan GYTS. ${ }^{11}$ Dimulai dari usia 10-14 tahun meningkat lebih dari $100 \%$ dalam kurun waktu kurang dari 20 tahun, yaitu dari $8,9 \%$ di tahun 1995 menjadi $18 \%$ di tahun 2013. ${ }^{7}$

Kebiasaan merokok dianggap dapat memberikan kenikmatan bagi perokok. Timbulnya rasa kepercayaan diri yang tinggi pada pelajar dan lebih meningkatkan konsentrasi dalam menghadapi masalah. ${ }^{6}$ Aspek psikologis turut berkontribusi dalam pola merokok di kalangan remaja. ${ }^{12}$ Menjadi perokok atau menjadi kecanduan merokok, merupakan proses dari berbagai tahap inisiasi dan adaptasi. ${ }^{12,13}$ Faktor pemungkin perilaku merokok berupa ketersediaan rokok di lingkungan sekolah siswa dan keterjangkauan uang saku siswa terhadap rokok. ${ }^{12}$

Merokok dapat menyebabkan berbagai macam penyakit, baik langsung oleh faktor merokok atau penyakit yang sudah ada sebelumnya dan diperburuk oleh merokok. ${ }^{13}$ Dalam pembahasan buku fakta tembakau 2014 oleh Kementerian Kesehatan RI dan TCSC menyatakan biaya pengobatan sakit dan disabilitas terkait penyakit yang di akibatkan oleh rokok 235,4 triliun rupiah, total biaya rawat jalan dan rawat inap 5,35 triliun rupiah, menyebabkan kerugian ekonomi sebesar 378,75 triliun rupiah. ${ }^{4}$

Berdasarkan hal diatas, maka perlu diteliti tentang keinginan berhenti merokok khususnya pada pelajar yang merokok di SMK Negeri di kota Padang. Pada penelitian ini dipilih siswa SMK Negeri di kota Padang yang merupakan kelompok usia dengan 15-17 tahun dikarenakan adanya peningkatan kejadian merokok terutama pada golongan usia ini. Penelitian ini dilakukan untuk melihat keinginan berhenti merokok pada pelajar perokok di SMK Negeri di Kota Padang khususnya pada tahun 2018. 
HASIL

Gambaran distribusi frekuensi perokok pada pelajar SMKN kota Padang pada tahun 2018 dapat dilihat pada Tabel 1.

Tabel 1. Distribusi frekuensi perokok pada pelajar SMK Negeri Kota Padang

\begin{tabular}{llll}
\hline \multirow{3}{*}{ Sekolah } & \multicolumn{2}{c}{ Klasifikasi } & Total \\
\cline { 2 - 3 } & & Perokok & \multicolumn{1}{c}{ Bukan } \\
& & Perokok \\
\hline SMKN 1 & $28(65,10 \%)$ & $15(34,90 \%)$ & $43(100 \%)$ \\
SMKN 2 & $6(14 \%)$ & $37(86 \%)$ & $43(100 \%)$ \\
SMKN 3 & $10(29,40 \%)$ & $24(70,60 \%)$ & $34(100 \%)$ \\
SMKN 4 & $19(41,30 \%)$ & $27(58,70 \%)$ & $46(100 \%)$ \\
SMKN 5 & $27(56,20 \%)$ & $21(43,80 \%)$ & $48(100 \%)$ \\
SMKN 6 & $15(36,60 \%)$ & $31(67,40 \%)$ & $46(100 \%)$ \\
SMKN 7 & $9(33.30 \%)$ & $18(66,70 \%)$ & $27(100 \%)$ \\
SMKN 8 & $24(75 \%)$ & $8(25 \%)$ & $32(100 \%)$ \\
SMKN 9 & $18(37,50 \%)$ & $30(62,50 \%)$ & $48(100 \%)$ \\
SMKN 10 & $10(55,60 \%)$ & $8(44,40 \%)$ & $18(100 \%)$ \\
\hline Total & $166(43,10 \%)$ & $219(56,90 \%)$ & $385(100 \%)$ \\
\hline
\end{tabular}

Tabel 1 memperlihatkan bahwa kurang dari separuh pelajar SMKN di kota Padang merupakan perokok dan lebih dari separuh siswa yang bukan perokok.

Gambaran distribusi frekuensi usia pertama kali merokok pada pelajar perokok di SMKN Kota Padang tahun 2018 dapat dilihat pada Tabel 2.

Pada Tabel 2 terlihat bahwa usia terbanyak mulai merokok pada pelajar perokok adalah pada umur 14-15 tahun.
Tabel 2. Distribusi frekuensi perokok pada pelajar di SMKN Kota Padang berdasarkan usia pertama kali mulai merokok

$\begin{array}{cccccc}<7 & 8-9 & 10-11 & 12-13 & 14-15 & >16 \\ \text { tahun } & \text { tahun } & \text { tahun } & \text { tahun } & \text { tahun } & \text { tahun }\end{array}$

\begin{tabular}{|c|c|c|c|c|c|c|}
\hline SMKN & 0 & 2 & 5 & 8 & 13 & 0 \\
\hline 1 & $(0 \%)$ & $(7,10 \%)$ & $(17,90 \%)$ & $(28,60 \%)$ & $(46,40 \%)$ & $(0 \%)$ \\
\hline $\begin{array}{c}\text { SMKN } \\
2\end{array}$ & $\begin{array}{c}0 \\
(0 \%)\end{array}$ & $\begin{array}{c}1 \\
(16,70 \%)\end{array}$ & $\begin{array}{c}1 \\
(16,70 \%)\end{array}$ & $\begin{array}{c}1 \\
(16,70 \%)\end{array}$ & $\begin{array}{c}3 \\
(50 \%)\end{array}$ & $\begin{array}{c}0 \\
(0 \%)\end{array}$ \\
\hline $\begin{array}{c}\text { SMKN } \\
3\end{array}$ & $\begin{array}{c}0 \\
(0 \%)\end{array}$ & $\begin{array}{c}1 \\
(10 \%)\end{array}$ & $\begin{array}{c}0 \\
(0 \%)\end{array}$ & $\begin{array}{c}3 \\
(30 \%)\end{array}$ & $\begin{array}{c}4 \\
(40 \%)\end{array}$ & $\begin{array}{c}2 \\
(20 \%)\end{array}$ \\
\hline $\begin{array}{c}\text { SMKN } \\
4\end{array}$ & $\begin{array}{c}0 \\
(0 \%)\end{array}$ & $\begin{array}{c}3 \\
(15,80 \%)\end{array}$ & $\begin{array}{c}2 \\
(10,50 \%)\end{array}$ & $\begin{array}{c}5 \\
(26,30 \%)\end{array}$ & $\begin{array}{c}9 \\
(47,40 \%)\end{array}$ & $\begin{array}{c}0 \\
(0 \%)\end{array}$ \\
\hline $\begin{array}{c}\text { SMKN } \\
5\end{array}$ & $\begin{array}{c}5 \\
(18,50 \%)\end{array}$ & $\begin{array}{c}3 \\
(11,1 \%)\end{array}$ & $\begin{array}{c}2 \\
(7,40 \%)\end{array}$ & $\begin{array}{c}7 \\
(25,90 \%)\end{array}$ & $\begin{array}{c}10 \\
(37 \%)\end{array}$ & $\begin{array}{c}0 \\
(0 \%)\end{array}$ \\
\hline $\begin{array}{c}\text { SMKN } \\
6\end{array}$ & $\begin{array}{c}0 \\
(0 \%)\end{array}$ & $\begin{array}{c}1 \\
(6,70 \%)\end{array}$ & $\begin{array}{c}3 \\
(20 \%)\end{array}$ & $\begin{array}{c}2 \\
(13,30 \%)\end{array}$ & $\begin{array}{c}9 \\
(60 \%)\end{array}$ & $\begin{array}{c}0 \\
(0 \%)\end{array}$ \\
\hline $\begin{array}{c}\text { SMKN } \\
7\end{array}$ & $\begin{array}{c}0 \\
(0 \%)\end{array}$ & $\begin{array}{c}0 \\
(0 \%)\end{array}$ & $\begin{array}{c}0 \\
(0 \%)\end{array}$ & $\begin{array}{c}4 \\
(44,40 \%)\end{array}$ & $\begin{array}{c}5 \\
(55,6 \%)\end{array}$ & $\begin{array}{c}0 \\
(0 \%)\end{array}$ \\
\hline $\begin{array}{c}\text { SMKN } \\
8\end{array}$ & $\begin{array}{c}1 \\
(4,20 \%)\end{array}$ & $\begin{array}{c}2 \\
(8,30 \%)\end{array}$ & $\begin{array}{c}4 \\
(16,70 \%)\end{array}$ & $\begin{array}{c}5 \\
(20,80 \%)\end{array}$ & $\begin{array}{c}4 \\
(16,70 \%)\end{array}$ & $\begin{array}{c}8 \\
(33,30 \%)\end{array}$ \\
\hline $\begin{array}{c}\text { SMKN } \\
9\end{array}$ & $\begin{array}{c}0 \\
(0 \%)\end{array}$ & $\begin{array}{c}2 \\
(11,10 \%)\end{array}$ & $\begin{array}{c}2 \\
(11,10 \%)\end{array}$ & $\begin{array}{c}3 \\
(16,70 \%)\end{array}$ & $\begin{array}{c}11 \\
(61,11 \%)\end{array}$ & $\begin{array}{c}0 \\
(0 \%)\end{array}$ \\
\hline $\begin{array}{c}\text { SMKN } \\
10\end{array}$ & $\begin{array}{c}1 \\
(10 \%)\end{array}$ & $\begin{array}{c}0 \\
(0 \%)\end{array}$ & $\begin{array}{c}0 \\
(0 \%)\end{array}$ & $\begin{array}{c}1 \\
(10 \%)\end{array}$ & $\begin{array}{c}4 \\
(40 \%)\end{array}$ & $\begin{array}{c}4 \\
(40 \%)\end{array}$ \\
\hline Total & $\begin{array}{c}7 \\
(4,21 \%)\end{array}$ & $\begin{array}{c}15 \\
(9,03 \%)\end{array}$ & $\begin{array}{c}19 \\
(11,46 \%)\end{array}$ & $\begin{array}{c}39 \\
(23,49 \%)\end{array}$ & $\begin{array}{c}72 \\
(43,37 \%)\end{array}$ & $\begin{array}{c}14 \\
(8,44 \%)\end{array}$ \\
\hline
\end{tabular}


Gambaran distribusi frekuensi perokok pada pelajar perokok di SMKN kota Padang tahun 2018 berdasarkan jenis kelamin dapat dilihat pada Tabel 3.

Tabel 3. Distribusi frekuensi perokok pada pelajar di SMKN Kota Padang berdasarkan jenis kelamin

\begin{tabular}{|c|c|c|c|}
\hline \multirow[b]{2}{*}{ Sekolah } & \multicolumn{2}{|c|}{ Klasifikasi } & \multirow[b]{2}{*}{ Total } \\
\hline & Laki-laki & Perempuan & \\
\hline \multirow[t]{2}{*}{ SMKN 1} & 28 & 0 & 28 \\
\hline & $(100 \%)$ & $(0 \%)$ & (100\%) \\
\hline \multirow[t]{2}{*}{ SMKN 2} & 6 & 0 & 6 \\
\hline & (100\%) & $(0 \%)$ & $(100 \%)$ \\
\hline \multirow[t]{2}{*}{ SMKN 3} & 10 & 0 & 10 \\
\hline & (100\%) & $(0 \%)$ & $(100 \%)$ \\
\hline \multirow[t]{2}{*}{ SMKN 4} & 19 & 0 & 19 \\
\hline & $(100 \%)$ & $(0 \%)$ & $(100 \%)$ \\
\hline \multirow[t]{2}{*}{ SMKN 5} & 27 & 0 & 27 \\
\hline & $(100 \%)$ & $(0 \%)$ & (100\%) \\
\hline \multirow[t]{2}{*}{ SMKN 6} & 13 & 2 & 15 \\
\hline & $(86,67 \%)$ & $(13,33 \%)$ & (100\%) \\
\hline \multirow[t]{2}{*}{ SMKN 7} & 9 & 0 & 9 \\
\hline & (100\%) & $(0 \%)$ & (100\%) \\
\hline \multirow[t]{2}{*}{ SMKN 8} & 24 & 0 & 24 \\
\hline & (100\%) & $(0 \%)$ & (100\%) \\
\hline \multirow[t]{2}{*}{ SMKN 9} & 18 & 0 & 18 \\
\hline & (100\%) & $(0 \%)$ & $(100 \%)$ \\
\hline \multirow[t]{2}{*}{ SMKN 10} & 10 & 0 & 10 \\
\hline & $(100 \%)$ & $(0 \%)$ & (100\%) \\
\hline \multirow[t]{2}{*}{ Total } & 164 & 2 & 166 \\
\hline & $(98,80 \%)$ & $(1,20 \%)$ & (100\%) \\
\hline
\end{tabular}

Pada tabel 3 dilihat bahwa sebagian besar perokok adalah pelajar laki-laki dan hanya sebagian kecil perokok adalah pelajar perempuan.

Gambaran distribusi frekuensi keinginan berhenti merokok pada pelajar perokok di SMKN kota Padang tahun 2018 dapar dilihat pada tabel 4.

Pada Tabel 4 dan Tabel 5 memperlihatkan bahwa hampir semua pelajar perokok berkeinginan untuk berhenti merokok, sebagian besar diantaranya pernah mencoba berhenti merokok dalam 12 bulan terakhir. Sebagian besar pelajar perokok menyadari jika ada kemauan mereka dapat berhenti merokok dan sebagian besar pernah mendapatkan nasehat dari teman maupun keluarga atau program berhenti merokok dari ahli.

Tabel 4. Distribusi frekuensi keinginan berhenti merokok pada pelajar SMKN di Kota Padang

\begin{tabular}{|c|c|c|c|c|}
\hline Sekolah & $\begin{array}{l}\text { Ingin } \\
\text { berhenti } \\
\text { mero- } \\
\text { kok } \\
\text { seka- } \\
\text { rang }\end{array}$ & $\begin{array}{c}\text { Pernah } \\
\text { mencoba } \\
\text { berhenti } \\
\text { merokok } \\
\text { dalam } 12 \\
\text { bulan } \\
\text { terakhir }\end{array}$ & $\begin{array}{c}\text { Dapat } \\
\text { berhenti } \\
\text { merokok } \\
\text { jika ada } \\
\text { kemauan }\end{array}$ & $\begin{array}{c}\text { Sedang } \\
\text { menda- } \\
\text { patkan } \\
\text { nasihat } \\
\text { berhenti } \\
\text { merokok }\end{array}$ \\
\hline \multirow{2}{*}{ SMKN 1} & 13 & 17 & 16 & 24 \\
\hline & $46,43 \%$ & $60,71 \%$ & $57,14 \%$ & $85,71 \%$ \\
\hline \multirow{2}{*}{ SMKN 2} & 4 & 3 & 6 & 5 \\
\hline & $66,67 \%$ & $50 \%$ & $100 \%$ & $83,33 \%$ \\
\hline \multirow[t]{2}{*}{ SMKN 3} & 9 & 9 & 8 & 9 \\
\hline & $90 \%$ & $90 \%$ & $80 \%$ & $90 \%$ \\
\hline \multirow[t]{2}{*}{ SMKN 4} & 13 & 13 & 11 & 14 \\
\hline & $68,42 \%$ & $68,42 \%$ & $57,89 \%$ & $73,68 \%$ \\
\hline \multirow[t]{2}{*}{ SMKN 5} & 13 & 18 & 17 & 25 \\
\hline & $48,15 \%$ & $66,67 \%$ & $62,96 \%$ & $92,59 \%$ \\
\hline \multirow[t]{2}{*}{ SMKN 6} & 10 & 13 & 12 & 14 \\
\hline & $66,67 \%$ & $86,67 \%$ & $80 \%$ & $93,33 \%$ \\
\hline \multirow[t]{2}{*}{ SMKN 7} & 6 & 5 & 9 & 9 \\
\hline & $66,67 \%$ & $55,56 \%$ & $100 \%$ & $100 \%$ \\
\hline \multirow[t]{2}{*}{ SMKN 8} & 16 & 19 & 22 & 23 \\
\hline & $66,67 \%$ & $79,17 \%$ & $91,67 \%$ & $95,83 \%$ \\
\hline \multirow[t]{2}{*}{ SMKN 9} & 17 & 16 & 16 & 18 \\
\hline & $94,44 \%$ & $88,89 \%$ & $88,89 \%$ & $100 \%$ \\
\hline \multirow{2}{*}{ SMKN 10} & 6 & 8 & 8 & 9 \\
\hline & $60 \%$ & $80 \%$ & $80 \%$ & $90 \%$ \\
\hline \multirow[t]{2}{*}{ Total } & 107 & 121 & 125 & 150 \\
\hline & $64,45 \%$ & $72,85 \%$ & $75,30 \%$ & $90,36 \%$ \\
\hline
\end{tabular}


Tabel 5. Distribusi frekuensi keinginan berhenti merokok pada pelajar SMKN di Kota Padang

\begin{tabular}{lccc}
\hline & \multicolumn{3}{c}{ Frekuensi } \\
\cline { 2 - 4 } & Ya & Tidak & Total \\
\hline Ingin berhenti & 107 & 59 & 166 \\
merokok sekarang & $(64,45 \%)$ & $(35,55 \%)$ & $(100 \%)$ \\
& & & \\
\hline Pernah mencoba & 121 & 45 & 166 \\
berhenti merokok & $(72,85 \%)$ & $(27,11 \%)$ & $(100 \%)$ \\
$\begin{array}{l}\text { dalam 12 bulan } \\
\text { terakhir }\end{array}$ & & & \\
& & & \\
\hline $\begin{array}{l}\text { Dapat berhenti } \\
\text { merokok jika ada }\end{array}$ & $(75,30 \%)$ & $(24,70 \%)$ & $(100 \%)$ \\
kemauan & \multicolumn{3}{|}{4166} \\
\hline $\begin{array}{l}\text { Pernah atau } \\
\text { sedang } \\
\text { mendapatkan } \\
\text { nasihat berhenti } \\
\text { merokok }\end{array}$ & 150 & $(9,64 \%)$ & $(100 \%)$ \\
\hline
\end{tabular}

\section{PEMBAHASAN}

Tabel 1 memperlihatkan bahwa kurang dari separuh pelajar SMKN di kota Padang merupakan perokok dan lebih dari separuh siswa yang bukan perokok. Hal ini sejalan dengan penelitian sebelumnya perokok pada pelajar SMA didapatkan $46,40 \%$ pelajar merupakan perokok dan 56,90 \% siswa yang bukan perokok. ${ }^{14}$ Perilaku merokok juga berasal dari pengaruh lingkungan dan individu. Remaja merokok berhubungan dengan krisis aspek psikososial yang dialami pada masa perkembangan yang bertepatan dengan masa remaja untuk mencari jati diri. Upaya menemukan jati diri tidak semua dapat berjalan sesuai harapan. ${ }^{12}$ Beberapa remaja melakukan perilaku merokok sebagai kompensasi akibat ketidaksesuaian tersebut. Remaja mengalami perubahan fisik yang bercampur dengan perubahan psikologis dan emosi yang membuat ketidaksiapan untuk menolak ajakan teman sebaya untuk mencoba rokok. Remaja mengikuti ajakan teman sebayanya sebagai pertahanan terhadap penolakan dan ketidaksesuaian di lingkungannya. ${ }^{6}$

Hasil penelitian pada Tabel 2 memperlihatkan bahwa usia terbanyak mulai merokok pada pelajar perokok adalah pada umur 14-15 tahun. Hal yang menarik didapatkan bahwa terdapat perokok yang mulai mencoba rokok pertama kali di usia kurang dari 7 tahun, hal ini menunjukkan bahwa semakin dini remaja bahkan anak mudah terpengaruh oleh rokok. Berdasarkan Riskesdas, prevalensi anak usia 5-9 tahun yang mulai merokok sebesar $1,60 \%$ dan anak usia 10 14 tahun sebesar 18\%, mereka dengan mudah mendapatkan rokok meski sudah ada larangan menjual rokok ke anak-anak. ${ }^{5}$ Data Sichletidis et al menunjukkan prevalensi perokok laki laki paling adalah pada umur 15-19 tahun atau seusia remaja di Sekolah Lanjutan Tingkat Atas. ${ }^{15}$ Rentang usia 12-15 tahun merupakan tahap yang paling mudah tepengaruh dengan hal-hal yang bersifat menarik, salah satunya rokok. $^{16}$ Kegiatan merokok yang dianggap simbol kegagahan membuat para remaja berlomba untuk mendapatkan perdiket tersebut. ${ }^{14}$ Remaja yang belum mempunyai pendirian kuat akan mudah terjerat dalam perilaku merokok, karena sebagian remaja beranggapan bahwa merokok adalah satu-satunya cara untuk dapat diterima dalam kelompoknya. ${ }^{16}$ Apabila remaja tidak mampu menolak, satu dua kali remaja merokok, lama kelamaan merokok akan menjadi kebiasaan.

Pada Tabel 3 dilihat bahwa sebagian besar perokok adalah pelajar laki-laki dan hanya sebagian kecil perokok adalah pelajar perempuan. Hal yang menarik adalah ditemukan dua orang perokok perempuan di SMKN 6 yang menunjukkan bahwa tidak tertutup kemungkinan bagi pelajar perempuan untuk merokok. Hasil penelitian ini juga bersamaan dengan berbagai negara berkembang dan juga negara maju. Berdasarkan Global Youth Tobacco Survey Timor Leste mendapatkan $66 \%$ laki-laki dan $24 \%$ perempuan pernah mencoba rokok. ${ }^{17}$ Menurut Riskesdas, peluang antara siswa yang berjenis kelamin laki-laki untuk merokok dibandingkan dengan siswa perempuan adalah 10,9 kali. ${ }^{5} \mathrm{Hal}$ ini disebabkan adanya perbedaan dalam perilaku remaja laki-laki yang berisiko, misalnya kencang saat membawa kendaraan, mengkonsumsi alkohol dan merokok. Prevalensi merokok pada laki-laki lebih tinggi dibandingkan perempuan juga dikarenakan merokok adalah simbol dari maskulinitas seorang lakilaki dan dianggap hal yang buruk apabila merokok dilakukan oleh perempuan. ${ }^{6,11}$ Jumlah remaja perempuan perokok di Indonesia memang tidak sebanyak jumlah remaja laki-laki perokok. Namun, dari 
data yang ada menyebutkan bahwa jumlah perokok perempuan terus meningkat. ${ }^{15}$ Stigma negatif masyarakat kepada perempuan perokok menggambarkan bahwa perokok perempuan tidak perduli pada pendapat orang lain. Perokok merasa bahwa merokok merupakan hak setiap orang, sehingga tidak perlu memikirkan apa kata orang lain. Bagi perokok selama perilakunya tidak merugikan orang lain, perokok tersebut akan mengabaikan orang lain. ${ }^{11}$

Berdasarkan Tabel 4 dan Tabel 5 dapat diketahui bahwa 107 (64,45\%) dari 166 orang pelajar perokok berkeinginan untuk berhenti merokok, 121 (72,89\%) dari 166 orang pelajar perokok pernah mencoba berhenti merokok dalam 12 bulan terakhir, $125(75,30 \%)$ dari 166 pelajar perokok beranggapan bahwa mereka mampu berhenti merokok jika ada keinginan dan kemauan dari diri mereka sendiri, dan 150 (90,36\%) dari 166 pelajar perokok mengatakan bahwa mereka pernah mendapat nasihat atau bantuan dari program dan profesional untuk berhenti merokok. Berdasarkan Factsheet Global Youth Tobacco Survey tahun 2014 di Indonesia memaparkan 4 dari 5 orang perokok berkeinginan untuk berhenti merokok. Banyak perokok mungkin menyadari risikonya dan termotivasi untuk berhenti merokok, namun mengalami kesulitan untuk berhenti merokok. Alasan gangguan kesehatan dan kerugian ekonomi hampir merata ditemukan pada perokok yang ingin menghentikan kebiasaan merokok. ${ }^{9}$ Dukungan dari orang terdekat juga menjadi motivasi untuk berhenti merokok. ${ }^{10}$

Banyak perokok mungkin menyadari risikonya dan termotivasi untuk berhenti merokok, namun mengalami kesulitan untuk berhenti merokok. Di Inggris dan Amerika Serikat, 40\% perokok melaporkan telah melakukan percobaan berhenti merokok. Selanjutnya, $50 \%$ dari usaha berhenti tidak melibatkan praperencanaan dan $75 \%$ usaha berhenti gagal pada minggu pertama. ${ }^{11}$ Perokok menyadari bahaya merokok terhadap lingkungan dan ini juga menjadi motivasi untuk berhenti merokok. Tahun 2007 40,50\% penduduk semua umur (91 juta) terpajan asap rokok di dalam rumah. Tahun 2010 prevalensi perokok pasif dialami oleh dua dari lima penduduk dengan jumlah berkisar 92 juta penduduk. Tahun 2013, jumlah ini meningkat menjadi sekitar 96 juta jiwa. Perempuan lebih tinggi
(54\%) dari pada laki-laki $(24,20 \%)$ dan anak usia 0-4 tahun yang terpajan adalah $56 \%$, atau setara dengan 12 juta anak terpajan asap rokok. ${ }^{4}$ Berhenti merokok diawali dengan niat dan bisa dibantu dengan metode berhenti merokok yang sudah dikembangkan oleh para ahli. Tidak ada obat yang bisa menghilangkan kebiasaan itu walaupun ada, sifatnya hanya sementara dan membutuhkan biaya yang mahal. Dengan bantuan orang-orang di sekitarnya, perokok bisa meninggalkan kebiasaan buruknya. ${ }^{12,13}$ Menghentikan kebiasaan merokok bukanlah usaha mudah terutama bagi perokok di Indonesia. Hasil survei lembaga menanggulangi masalah rokok. ${ }^{18}$ Sebanyak $66,20 \%$ perokok pernah mencoba berhenti merokok tetapi tidak berhasil. Kegagalan ini disebabkan karena tidak tahu caranya sebanyak 42,90\%, 2,90\% terikat sponsor rokok. Sedangkan yang berhasil berhenti merokok disebabkan oleh kesadaran sendiri sebanyak $76 \%, 16 \%$ sakit, $8 \%$ tuntutan profesi. $^{18}$

Berbagai upaya berhenti merokok terdapat dalam pedoman (guideline) yang telah di kembangkan oleh ahli. Hal yang pertama kali dilakukan adalah identifikasi perokok untuk mendapatkan kesadaran dan niat kemudian memberi motivasi mereka untuk berhenti merokok, selanjutnya berikan dukungan dengan cara konseling, farmakoterapi dan follow up secara teratur. ${ }^{16}$

\section{SIMPULAN}

Hampir semua pelajar perokok berkeinginan untuk berhenti merokok, sebagian besar diantaranya pernah mencoba berhenti merokok dalam 12 bulan terakhir, sebagian besar pelajar perokok menyadari jika ada kemauan mereka dapat berhenti merokok, sebagian besar pernah mendapatkan nasehat dari teman maupun keluarga atau program berhenti merokok dari ahli.

\section{DAFTAR PUSTAKA}

1. Organisation for Economic Co-operation and Development Economic Surveys Indonesia. Survei ekonomi Indonesia 2015. (diunduh Oktober 2017). Tersedia dari: http://www.oecd.org/eco/surveys/ economic-surveyindonesia.htm 
2. Hadi PU, Friatno S. Peranan sektor tembakau dan industry rokok dalam perekonomian Indonesia: analisis tabel I-O tahun 2000. Jurnal Agroekonomi. 2008; 26(1):93-113.

3. Kementerian Kesehatan RI. Buku bunga rampai fakta tembakau dan permasalahannya di Indonesia. Jakarta Pusat: Tobacco Control Support Centre IAKMI; 2014

4. Menteri Perindustrian Indonesia. Industri rokok libatkan tenaga kerja 6,1 juta orang. 2015 (diunduh Desember 2017). Tersedia dari: https://finance.detik.com/industri/2872087/ menperin-industri-rokok-libatkan-tenaga-kerja-61juta-orang

5. Kementerian Kesehatan RI. Riset kesehatan dasar (Riskesdas) 2013. Jakarta: Kementerian Kesehatan $\mathrm{RI} ; 2013$.

6. Setiyanto D. Perilaku merokok dikalangan remaja: studi kasus tentang faktor dan dampak dari perilaku merokok pada kalangan pelajar SMA Negeri 2 Karanganyar (disertasi). Surakarta: Universitas Sebelas Maret; 2013.

7. World Health Organization (WHO). A global youth tobacco survey 2008. Gambia: WHO press; 2008.

8. Rizanna R. Antara motivasi dan tantangan berhenti merokok (studi kasus mahasiswa di Banda Aceh). Jurnal Komunikologi. 2013;10(1):9-16.

9. Rosita R, Suswardany DL, Abidin Z. Penentu keberhasilan berhenti merokok pada mahasiswa Fakultas IImu Kesehatan Muhammadiyah Surakarta. Jurnal Kesehatan Masyarakat. 2012; 8(1):1-10.

10. Abikoye EG, Kashimawo AJ, Eze CU. Tobacco smoking and awareness of smoking-cessation products in a university community. Academic Journal. 2013; 5(8): 351-6.
11. Kementerian Kesehatan RI. Infodatin Pusat Data dan Informasi Kementerian Kesehatan RI: Perilaku Merokok Masyarakat Indonesia Berdasarkan Riskesdas 2007 dan 2013. Jakarta: Kementerian Kesehatan RI; 2015.

12. $\mathrm{Ng} \mathrm{N}$, Weinehall $\mathrm{L}$, Ohman A. If I don't smoke, i'm not a real man-Indonesian teenage boys view about smoking. Health Education Research. 1st edition. London: Oxford University Press. 2006.hlm.1-11.

13. Nururrahmah. Pengaruh rokok terhadap kesehatan dan pembentukan karakter manusia. Prosiding Seminar Nasional Universitas Cokroaminoto Palopo. 2014;1(1):78-83.

14. Adilla AT. Pengaruh merokok terhadap keluhan respirasi pada siswa SMA N 9, SMA N 10, dan SMA N 14 Padang (skripsi). Padang: Universitas Andalas; 2017.

15. Sichletidis LT, Chloros DA, Tsiotsios AI, Spyratis DG. Prevalence and Risk factors for initiation of smoking in greek high-school students. International Journal Enviroment Res. Public Health. Thessaloniki: Aristotle University of Thessaloniki. 2009;6(3):971-9.

16. Firzawati. Faktor upaya berhenti merokok pada perokok aktif umur 15 tahun keatas di Indonesia (disertasi). Depok: Universitas Indonesia; 2015.

17. World Health Organization (WHO). Timor Leste 2013 (ages 13-15) Global Youth Tobacco Survey: Fact Sheet. New Delhi: WHO-SEARO. 2013:1-2.

18. Amalia R, Trixie S. Perilaku merokok di kalangan mahasiswa Universitas Muhammadiyah Semarang: smoking behavior among student in Universitas Muhammadiyah Semarang. Prosiding Seminar Nasional Universitas Muhammadiyah Semarang. 2010:172-8. 